\title{
Micropropagation Studies in Papaya (Carica papaya L.) cv. 'Surya'
}

\author{
Shivayogi Ryavalad ${ }^{1 *}$, T.A. Malabasari ${ }^{2}$, T. Shantappa ${ }^{3}$, D.S. Uppar ${ }^{4}$, \\ B.D. Biradar ${ }^{5}$ and S.M. Mantur
}

${ }^{1}$ Department of Seed Science and Technology, College of Agriculture, UAS, Dharwad, India

${ }^{2} \mathrm{AEU}$, Mudhol, ${ }^{3} \mathrm{SST}, \mathrm{COH}$, Sirasi, ${ }^{4} \mathrm{SST}, \mathrm{ACD}, \mathrm{UAS}$, Dharwad, ${ }^{5}$ GPB, ACD, UAS, Dharwad

${ }^{6} H R T, A C$, Hanumanmatti UAS, Dharwad, India

*Corresponding author:

\section{A B S T R A C T}

\section{Keywords}

Polygamous, Sex expression, Micropropagation, Benzylaminopurine, Naphthalene acetic acid

Article Info

Accepted:

17 March 2019

Available Online:

10 April 2019

\begin{abstract}
Papaya is one of the few important fruits which flowers and yield throughout the year. Though a polygamous species with three basic types viz., staminate, pistillate and bisexual, its cultivation with seed propagation is hindered by problems due to vide variability in sex expression and fruit characters. In such point of view, propagation through asexual method could be a better alternative. The micropropagation will substitute method of propagation by cutting or grafting would be of great boon to papaya industry. The procedure for in vitro propagation of papaya (Carica papaya) cv. Surya was developed by culturing shoot tips on Murashige and Skoog (MS)-medium supplemented with different concentration of (BAP) Benzylaminopurine like 0.5, 1.0, 2.0 and $2.0 \mathrm{mg} / \mathrm{l}$ and 2.0 $\mathrm{mg} / \mathrm{l} \mathrm{BAP}+1.0 \mathrm{mg} / \mathrm{l}$ (NAA) naphthalene acetic acid. Among different combinations of growth regulators $2.0 \mathrm{mg} / \mathrm{l} \mathrm{BAP}+1.0 \mathrm{mg} / \mathrm{l}$ (NAA) was the best for shoot multiplication. The best results of root formation as well as root length were obtained using $3 \mathrm{mg} / \mathrm{l}$ NAA. Successful transplanting was observed when the plantlets were transferred into pots contained peat moss and sand $(1: 1)$.
\end{abstract}

\section{Introduction}

Papaya is considered one of the important fruit crops in many tropical and subtropical countries. It is rich source of carbohydrates, minerals, vitamin $\mathrm{A}$ and $\mathrm{C}$, pectin, alkaloid and carpine. Papaya is used as fresh, ripened fruit as well as raw vegetable. This fruit is gaining more importance due to extraction of latex which is known to contain an enzyme papain and chymopapain 1. The papain is used in tenderizing of meat, manufacture of cosmetics, curing of leather, brewing, chill proofing of beer and treatment of digestive disorders. Biologically papaya plant has three types of flowers such as male, female and bisexual but only female and bisexual types are productive. In commercial plantation it is very often found that male plants prevail as high as $30 \%$ and some times over $50 \%$ of the total (Jordan et al., 1983).

It is conventionally propagated by seeds and therefore, cultivation is hindered by problems 
due to its inherent heterozygosity and dioecious in nature (Rajeevan and Pandey, 1986). Plants grown from seeds of open pollinated flowers result in a mixture of genotypes, with a considerable variation in disease susceptibility, fruit quality and yield. Although conventional vegetative propagation methods such as grafting and rooted cuttings exist (Allan, 1964), they are often tedious and impractical when carried out on a large scale. Tissue culture techniques could offer a valuable alternative and reliable procedure for mass propagation of homogenous and uniform plants for both commercial and research purposes. As the sex of explants is known, the required proportion of male to female plants could be produced. This method could also facilitate the rapid propagation of superior selected lines. In vitro propagation of papaya through regeneration from callus (Yie and Liaw, 1977) or from multiple shoot cultures (Litz and Conover, 1978; Rajeevan and Pandey, 1983) have been attempted. In this study attempts were made to develop a procedure for rapid mass propagation of papaya through tissue culture.

\section{Materials and Methods}

The seeds of Carica papaya L. cv. Surya were collected from Indian Institute of Horticultural Research (IIHR), Hesargatta, Bangalore and raised in the nursery of the University of Horticultural Sciences, Bagalkot, Karnataka. Cultivar Surya is the hybrid derivative of SUNRISE SOLO $X$ PINK FLESH SWEET released from IIHR, Bangalore. It is gynodioecious smooth skinned flesh has attractive red colour, soft, crisp, free from typical papaya odour with high TSS which is used for explants for the present investigation. Plant materials like young leaves/shoot tip were collected in a beaker containing tap water to avoid desiccation. Surface sterilization was done under aseptic conditions in laminar air flow cabinet. They were surface sterilized with $70 \%$ ethyl alcohol $(1 \mathrm{~min})$ followed by $0.1 \%$ $\mathrm{HgCl} 2$ for $2 \mathrm{~min}$. After surface sterilization, lateral buds and young leaves were divided into small pieces (approx. $1.0-1.5 \mathrm{~cm}$ ). These were used as explants and cultured onto culture medium. MS containing 3\% sucrose was used for all shoot and for in vitro root formation. The various stock solutions and plant growth regulators were dispensed separately. The $\mathrm{pH}$ of the medium containing all the above components was adjusted to 5.8 by using $0.1 \mathrm{~N} \mathrm{HCl}$ or $\mathrm{NaOH}$. The culture bottles containing the medium were steam sterilized in autoclave (pressure: $1.06 \mathrm{Kg} / \mathrm{cm}^{2}$; temperature $121^{\circ} \mathrm{C}$ ) for 15 to 20 minutes. After sterilization, the culture tubes with the prepared media were allowed to cool at room temperature. All the cultures were grown at $26 \pm 2{ }^{\circ} \mathrm{C}$ under a 16-h photoperiod. The illumination was provided by cool white fluorescent tubes at a light intensity of 30-40 $\mu$ mol m-2 S-1 PAR. The influence of BAP, and NAA, were evaluated in various experiments as described below.

The apical meristem of the Papaya cultivar as established on MS medium containing various levels of benzyl amino purine (BAP) by following usual aseptic procedures. These were sub cultured on the respective medium after 25 days of incubation. The meristem normally grew into a single shoot. Such shoots were allowed to grow further and produce multiple shoots. The shoots so obtained were transferred to MS medium containing various combinations and concentrations of growth regulators viz., BAP and NAA. The multiple shoot cultures were routinely maintained by sub culturing a bunch of 2-3 shoots after every 25 days.

\section{Treatment details}

The details of the treatment are as follows $\mathrm{S}_{1}$ : MS basal medium 
$\mathrm{S}_{2}: \mathrm{MS}+0.5 \mathrm{mg} / \mathrm{l} \mathrm{BAP}$

$\mathrm{S}_{3}: \mathrm{MS}+1.00 \mathrm{mg} / \mathrm{BAP}$

$\mathrm{S}_{4}: \mathrm{MS}+2.00 \mathrm{mg} / \mathrm{l} \mathrm{BAP}$

$\mathrm{S}_{5}: \mathrm{MS}+2.00 \mathrm{mg} / \mathrm{l} \mathrm{BAP}+1.00 \mathrm{mg} / \mathrm{l} \mathrm{NAA}$ basal

The multiple shoots obtained from shoot proliferation medium were separated and individual shoots were transferred to MS medium supplemented with different levels of NAA for rooting.

$\mathrm{S}_{1}$ : MS

$\mathrm{S}_{2}: \mathrm{MS}+0.5 \mathrm{mg} / \mathrm{NAA}$

$\mathrm{S}_{3}: \mathrm{MS}+1.00 \mathrm{mg} / \mathrm{l} \mathrm{NAA}$

$\mathrm{S}_{4}: \mathrm{MS}+2.00 \mathrm{mg} / \mathrm{l} \mathrm{NAA}$

$\mathrm{S}_{5}: \mathrm{MS}+3.00 \mathrm{mg} / \mathrm{l} \mathrm{NAA}$

\section{Culture details}

Culture medium: Murashige and Skoog Volume of the medium: $16 \mathrm{ml} /$ Culture. $\mathrm{pH}-$ 5.8

Number of replications: 5 No of cultures/replications $=5$

Culture conditions: Temperature: $26 \pm 2^{0} \mathrm{C}$. Light/Dark period: 16/8 Hrs

Culture period: 28 days. Inoculums: $300 \pm 10$ mg / Culture

For acclimatization, the rooted plantlets were carefully removed from the culture tubes. The roots of the plantlets were gently washed under running tap water to remove agar attached to the root zone. Immediately after washing they were transferred to small earthen pots containing a mixture of soil, sand and compost in 2: 1: 1 ratio. Finally acclimatized plantlets were transferred to the field.

\section{Experimental Results}

\section{Initiation and establishment of meristem culture}

Apical meristems of papaya cultivar "Surya" were inoculated with different concentrations of BAP for shoot initiation. Small shoots started appearing within 20-25 days in many of the culture tubes. Initially there was problem of tissue browning which slightly hindered the shoot growth. Sub culturing was done frequently (25 days) during the early stages of establishment to reduce the adverse effect of browning of tissues and the release of pigments in the medium. The per cent establishment varied between different levels of BAP. The frequency of establishment was the highest (72\%) on MS medium with 2.0 $\mathrm{mg} / \mathrm{l}$, BAP followed by $1 \mathrm{mg} / \mathrm{l}$, BAP $(20 \%)$ and the lowest was with $0.5 \mathrm{mg} / \mathrm{l} \mathrm{BAP} \mathrm{(8 \% ),}$ when compared with control (Table 1). The treatment with MS + BAP $(2.00 \mathrm{mg} / \mathrm{l})$ was significantly superior to any other treatment for establishment of culture.

Frequency of establishment was maximum with $2.0 \mathrm{mg} / \mathrm{l} \mathrm{BAP}$, on which shoots were active and healthy, compared to other treatments. At this level of BAP at the end of 25th day, 10 - 15 shoots originated from single meristem (Table 2).

\section{Shoot multiplication}

Once the meristems were established and sufficient number of shoots were available, an experiment involving various concentrations and combinations of growth regulators, viz., $\operatorname{BAP}(0.0,0.5,1.0$ and $2.0 \mathrm{mg} / \mathrm{l})$ and BAP $(2$ $\mathrm{mg} / \mathrm{l})+\mathrm{NAA}(1 \mathrm{mg} / \mathrm{l})$ was conducted to study their effect on shoot multiplication. The rate of multiplication at different level of concentration of growth regulators is the highest rate of multiplication 79.64 per cent was recorded at $2.0 \mathrm{mg} / \mathrm{l} \mathrm{BAP} \mathrm{+} \mathrm{NAA} \mathrm{and} \mathrm{the}$ least multiplication of 7.56 per cent with BAP (0.05) while in control it was 2.08 per cent. The combination of BAP + NAA treatment resulted in more plantlets. The mean rate of multiplication was 0.05 at $2.0 \mathrm{mg} / \mathrm{l} \mathrm{BAP}$ and was significantly superior to other treatments except the one with $2.0 \mathrm{mg} / \mathrm{l} \mathrm{BAP}+1.0 \mathrm{mg} / \mathrm{l}$ NAA (Fig. 1). 
Table.1 Effect of BAP on establishment of shoots

\begin{tabular}{|c|c|c|c|c|}
\hline $\begin{array}{c}\text { Si. } \\
\text { No. }\end{array}$ & Treatment & $\begin{array}{c}\text { Concentration of } \\
\text { growth regulator }(\mathbf{m g} / \mathbf{l})\end{array}$ & $\begin{array}{c}\text { No. of shoot } \\
\text { tips } \\
\text { inoculated }\end{array}$ & $\begin{array}{c}\text { No. of shoot tip } \\
\text { established }\end{array}$ \\
\hline $\mathbf{1}$ & MS & $\mathbf{0 . 0 0}$ & $\mathbf{2 5}$ & $\mathbf{0}(\mathbf{0 . 0 0})$ \\
\hline $\mathbf{2}$ & MS + BAP & $\mathbf{0 . 0 5}$ & $\mathbf{2 5}$ & $\mathbf{2}(\mathbf{8 . 0 0})$ \\
\hline 3 & MS + BAP & $\mathbf{1 . 0 0}$ & $\mathbf{2 5}$ & $\mathbf{4}(\mathbf{2 0 . 0 0})$ \\
\hline $\mathbf{4}$ & MS + BAP & $\mathbf{2 . 0 0}$ & $\mathbf{2 5}$ & $\mathbf{1 8}(\mathbf{7 2 . 0 0})$ \\
\hline & Mean & - & - & $\mathbf{6 . 0 0}$ \\
\hline & SEm \pm & - & - & $\mathbf{0 . 2 7}$ \\
\hline & CD $(0.01)$ & - & - & $\mathbf{1 . 1 3}$ \\
\hline
\end{tabular}

** Values outside the parenthesis are transformed, where as in parenthesis are actual values

Table.2 Effect of BAP on regeneration of shoot tip explants

\begin{tabular}{|c|c|c|c|}
\hline Si. No & Treatments & $\begin{array}{c}\text { Concentration of } \\
\text { growth } \\
\text { regulator }(\mathbf{m g} / \mathbf{l})\end{array}$ & $\begin{array}{c}\text { Average number of shoots per } \\
\text { culture (Multiple shoots) }\end{array}$ \\
\hline 1 & MS & $\mathbf{0 . 0 0}$ & $\mathbf{3 0}$ DAI \\
\hline 2 & MS + BAP & $\mathbf{0 . 0 5}$ & $\mathbf{1 . 8 9}(\mathbf{7 . 5 6})$ \\
\hline 3 & MS + BAP & 1.00 & $\mathbf{2 . 0 1}(\mathbf{8 . 0 4})$ \\
\hline 4 & MS + BAP & $\mathbf{2 . 0 0}$ & $\mathbf{5 . 4 6}(\mathbf{2 1 . 8 4})$ \\
\hline 5 & MS + BAP +NAA & $\mathbf{2 . 0 0 + 1 . 0 0}$ & $\mathbf{1 9 . 9 1 ( 7 9 . 6 4 )}$ \\
\hline & Mean & - & $\mathbf{5 . 9 6}$ \\
\hline & SEm \pm & - & $\mathbf{0 . 0 3}$ \\
\hline & CD $(\mathbf{0 . 0 1})$ & - & $\mathbf{0 . 1 0}$ \\
\hline
\end{tabular}

** Values outside the parenthesis are transformed, where as in parenthesis are actual values

Table.3 Effect of BAP on regeneration of rooting

\begin{tabular}{|c|c|c|c|}
\hline Si. No & Treatments & $\begin{array}{c}\text { Concentration of } \\
\text { growth } \\
\text { regulator }(\mathbf{m g} / \mathbf{l})\end{array}$ & $\begin{array}{c}\text { Average number of shoots per } \\
\text { culture (Multiple shoots) }\end{array}$ \\
\hline $\mathbf{1}$ & MS & $\mathbf{0 . 0 0}$ & $\mathbf{3 0}$ DAI \\
\hline $\mathbf{2}$ & MS + NAA & $\mathbf{0 . 0 5}$ & $\mathbf{6}(\mathbf{6 0 . 0 0})$ \\
\hline 3 & MS + NAA & $\mathbf{1 . 0 0}$ & $\mathbf{7}(\mathbf{7 0 . 0 0})$ \\
\hline 4 & MS + NAA & $\mathbf{2 . 0 0}$ & $\mathbf{7}(\mathbf{7 0 . 0 0})$ \\
\hline $\mathbf{5}$ & MS + NAA & $\mathbf{3 . 0 0}$ & $\mathbf{8}(\mathbf{8 0 . 0 0})$ \\
\hline & Mean & - & 6.6 \\
\hline & SEm \pm & - & $\mathbf{0 . 3 2}$ \\
\hline & CD $(\mathbf{0 . 0 1})$ & - & $\mathbf{1 . 2 7}$ \\
\hline
\end{tabular}

** Values in parenthesis are in percentage 
Fig.1

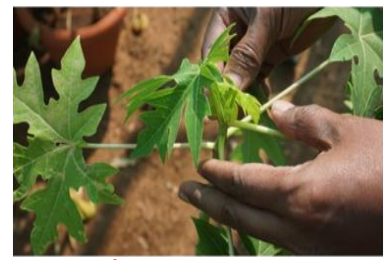

a) Mother plant

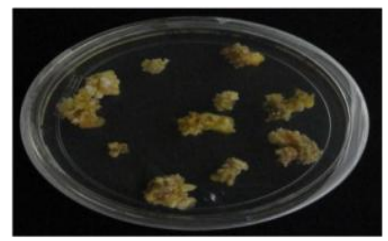

d) Shoot proliferation

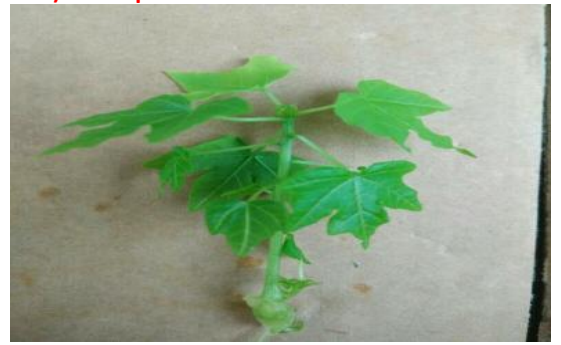

f) In vitro developed shoot

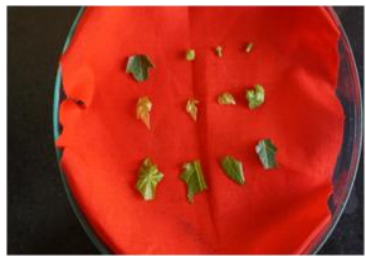

b) Different Explants Used

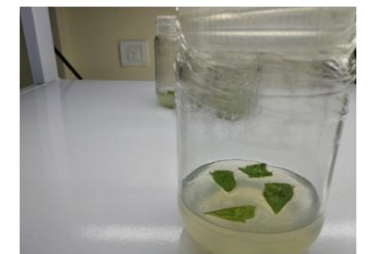

c) Explants Incubated in media (MS+GR)
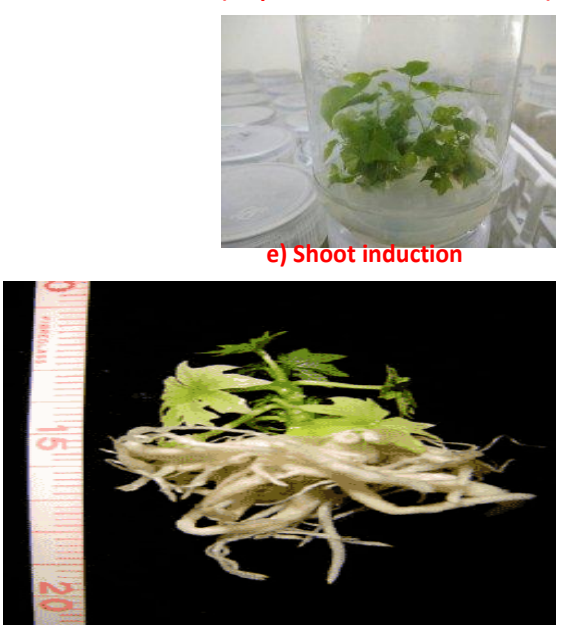

g) In vitro developed root

\section{Rooting of shoots}

In vitro (21-28 days old) devoid of roots were cultured on different media containing NAA namely $0.0 \mathrm{mg} / \mathrm{l}, 0.5 \mathrm{mg} / \mathrm{l}, 1 \mathrm{mg} / \mathrm{l}, 2 \mathrm{mg} / \mathrm{l}$ and $3 \mathrm{mg} / \mathrm{l}$ to induce roots. The frequency of rooting in different concentration of NAA in Papaya is presented in Table 3. Rooting response was lower in treatment containing with NAA $0.00 \mathrm{mg} / \mathrm{l}(50 \%)$ and the highest percentage of rooting was in NAA with 3.0 $\mathrm{mg} / \mathrm{l}(80 \%)$. The nature of rooting was similar in all the treatments but the root induction percentage varied with the concentration of NAA.

In conclusion, among different combinations of growth regulators $2.0 \mathrm{mg} / \mathrm{l} \mathrm{BAP}+1.0 \mathrm{mg} / \mathrm{l}$ (NAA) was the best for shoot multiplication.
The best results of root formation as well as root length were obtained using $3 \mathrm{mg} / \mathrm{l}$ NAA. Successful transplanting was observed when the plantlets were transferred into pots contained peat moss and sand $(1: 1)$.

\section{References}

Allan. P,1964. Papaya grown from cuttings. Farming $S$ A fr, 39: 35-40.

Ahmad. N and Anis. M, 2007. Rapid plant regeneration protocol for cluster bean (Cyamopsis tetragonoloba L.Taub.). J. Horticultural Sci. Biotechnology, 84: 585- 589.

Bhattacharya. J and Khuspe. S. S, 2001. In vitro and in vivo germination of papaya (Carica papaya L.) seeds. Scientia Horticulturae, 91: 39- 49. 
Bhattacharya. J, Khuspe. S. S, Renukdas. N. $\mathrm{N}$ and Rawal. S. K, 2003, Somatic embryogenesis and plant regeneration from immature embryo explants of papaya cv. Washington and Honey Dew. Indian J. Exp. Biol, 40: 624-627.

Jordan. M, Cortes. I and Montenegro. G, 1983. Regeneration of plants by embryogenesis from callus cultures of Carica candamarcensis. Plant Sci. Let, 28: 321-326.

Litz. R. E and Conover. R. A, 1978. In vitro propagation of papaya. HortScience, 13: 241:242.

Murashige. T and Skoog. F. A, 1962. revised medium for rapid growth and bioassays with tobacco tissue cultures. Physiol. Plant, 15:473- 97.
Rajeevan. M. S and Pandey. R. M, 1986, Lateral bud culture of papaya (Carica papaya $L$.) for clonal propagation. Plant Cell, Tissue and Organ Culture, 5:181188.

Ramesh. A. N, Santhosh. D. B, Suresh. D, Radha Krishna, Rashmi. K and Hajira Khanm, 2018. In Vitro Regeneration of Papaya (Carica papaya L.) Variety Surya, Int. J. Pure App. Biosci, 6 (4): 456-461.

Skoog. F and Miller. C. O, 1957. Chemical regulation of growth and organ function in plant tissues cultured in vitro. Symp., Soc. exp. Biol, 11:118- 131.

Yie.S.Y and Liaw. S.I, 1977. Plantlet regeneration from shoot-tips and callus of papaya. In vitro, 13,564:568.

\section{How to cite this article:}

Shivayogi Ryavalad, T.A. Malabasari, T. Shantappa, D.S. Uppar, B.D. Biradar and Mantur, S.M. 2019. Micropropagation Studies in Papaya (Carica papaya L.) cv. 'Surya'. Int.J.Curr.Microbiol.App.Sci. 8(04): 2362-2367. doi: https://doi.org/10.20546/ijcmas.2019.804.275 